\title{
Studi Semiotika Pada Mural Di Jalan (Analisis Roland Barthes Pada Mural Yang Dihapus Setelah Viral)
}

\author{
Bernica Irnadianis Ifada ${ }^{1}$, Suzy S. Azeharie ${ }^{2}$ \\ ${ }^{1}$ Fakultas Ilmu Komunikasi, Universitas Tarumanagara, Jakarta \\ Email:bernica.915180141@stu.untar.ac.id \\ ${ }^{2}$ Fakultas Ilmu Komunikasi, Universitas Tarumanagara, Jakarta* \\ Email: suzya@fikom.untar.ac.id
}

Masuk tanggal : 15-12-2021, revisi tanggal :06-01-2022, diterima untuk diterbitkan tanggal : 16-01-2022

\begin{abstract}
Mural is an art in the form of street art which is a medium of communication that is often used by the public to convey messages, hopes, and community criticisms to those in power. The Covid-19 pandemic is spreading rapidly around the world. The government makes policies and strategies to stop the spread of Covid-19. However, this resulted in many people being disappointed and dissatisfied. This dissatisfaction was shown by several people by making murals. This study will examine how the meaning of murals on the street are deleted after they go viral. The purpose of this study was to find out the meaning of the murals on the street was deleted after they go viral. The theory used in this research is the public sphere, the semiotics of Rolland Barthes, and the silent group. This research uses a descriptive qualitative research approach with the semiotic analysis method of Roland Barthes. The research data were obtained from observations, documentation studies, and literature studies. The conclusion of this study is that in public spaces, murals are used as social criticism. However, this mural often causes a lot of noise and the officers or officers reactively delete the messages as a form of silence.
\end{abstract}

Keywords: murals, public sphere, silent group

\begin{abstract}
Abstrak
Mural merupakan seni yang berbentuk street art yang menjadi media komunikasi yang kerap digunakan oleh masyarakat untuk menyampaikan pesan, harapan dan kritik masyarakat kepada pihak yang memiliki kekuasaan. Pandemi Covid-19 menyebar dengan cepat keseluruh dunia. Pemerintah membuat kebijakan dan strategi dalam menghentikan penyebaran Covid19. Namun mengakibatkan banyak masyarakat yang kecewa dan merasa tidak puas. Ketidakpuasan itu ditunjukan beberapa masyarakat dengan membuat mural. Penelitian ini akan meneliti bagaimana makna pada mural di jalan yang dihapus setelah viral. Tujuan dari penelitian ini adalah untuk mengetahui makna pada mural di jalan yang dihapus setelah viral. Teori yang digunakan peneliti adalah ruang publik, semiotika Roland Barthes, dan kelompok bungkam. Penelitian ini menggunakan pendekatan penelitian kualitatif deskriptif dan menggunakan metode analisis semiotika Roland Barthes. Data penelitian diperoleh dari pengamatan, studi dokumentasi dan studi kepustakaan. Kesimpulan dalam penelitian ini adalah di ruang publik, mural digunakan sebagai kritik sosial. Namun mural ini kerap menimbulkan banyak kegaduhan lalu petugas atau aparat secara reaktif menghapus pesanpesan itu sebagai bentuk pembungkaman.
\end{abstract}

Kata Kunci : mural, ruang publik, kelompok bungkam 


\section{Pendahuluan}

Di Indonesia, sejak masa pra kemerdekaan mural banyak digunakan untuk menyalurkan semangat kemerdekaan pada rakyat Indonesia. Dan sejalan dengan perkembangan waktu mural memunculkan komunitas seperti Taring Padi dan Apotik Komik di era1990-an, sehingga mural sering disebut sebagai media untuk publik berekspresi dan menyuarakan pendapat (Muhid, 2021).

Pemerintah di Indonesia mengumumkan dua kasus pasien positif Covid-19 pertama kali di Indonesia adalah pada tanggal 2 Maret 2020 (Pranita, 2020). Pandemi Covid-19 ini menyebar dengan sangat cepat keseluruh penjuru dunia dan menyebabkan kepanikan masyarakat. Perekonomian banyak negara terpukul hebat termasuk di Indonesia. Untuk mencegah meluasnya wabah ini serta menggerakan roda pereknomian dalam waktu yang bersamaan, pemerintah membuat berbagai kebijakan dan strategi dalam mencegah transmisi dan mencegah tingkat kematian akibat wabah penyakit ini (Nasruddin, 2020).

Strategi yang dilakukan pemerintah untuk menghentikan penyebaran Covid-19 adalah dengan memberlakukan kebijakan Pembatasan Sosial Berskala Besar (PSBB) dan diteruskan dengan Pemberlakuan Pembatasan Kegiatan Masyarakat (PPKM) (Indonesiabaik.id, 2021). Pembatasan Sosial Berskala Besar (PSBB) merupakan pembatasan kegiatan penduduk dalam suatu wilayah antara lain, peliburan sekolah dan tempat kerja, pembatasan kegiatan di tempat umum hingga pembatasan moda transportasi. Sedangkan Pemberlakuan Pembatasan Kegiatan Masyarakat(PPKM) merupakan pembatasan kegiatan masyarakat secara terbatas di Kota dan Kabupaten dengan membatasi kegiatan perkantoran dan sebesar $75 \%$ menerapkan kerja dari rumah atau Work From Home(WFH) dan 25\% kerja di kantor atau Wok From Office (WFO), dan dalam pelaksanaan kegiatan belajar mengajar secara dalam jaringan (daring), lalu makan di tempat diperbolehkan dengan syarat kapasitas sebesar 25\%, serta pembatasan jam operasional sampai dengan pukul 19.00 WIB (Harbani, 2021).

Namun kebijakan dan strategi yang dilakukan pemerintah ini mengakibatkan banyak masyarakat yang tertekan karena aktivitas terhambat. Berdasarkan data Badan Pusat Statistik (BPS) tahun 2020, pengangguran di Indonesia telah mencapai 2,56 juta dari 29,12 juta jumlah penduduk usia kerja (Pranata, 2021).

Selain itu, macam respon dan persepsi dari masyarakat tentang ketidakpuasan terhadap pemerintah meningkat. Ada 87, 8\% responden yang disurvei oleh Litbang KOMPAS merasa tidak puas terhadap kinerja pemerintah khususnya dalam menangani pandemi Covid-19 (KOMPAS, 13 Juli 2020).

Ketidakpuasan itu ditunjukan beberapa masyarakat dengan membuat mural. Mural yang mengekspresikan ketidakpuasan terhadap pemerintah antara lain:

a. Mural berjudul 'Tuhan Aku Lapar' karya anggota Halfway Street Connection yang terdapat di kawasan Kotamas, Tigaraksa, Kabupaten Tangerang.

b. Mural berjudul 'Dipaksa Sehat di Negara yang Sakit' terdapat di Jalan Diponegoro, Bangil, Pasuruan, Jawa Timur.

c. Mural berjudul '404: Not Found' bergambar sosok mirip Presiden Joko Widodo yang pada bagian matanya ditutupi tulisan '404: Not Found'. Lokasi mural tersebut berada di Batuceper, Kota Tangerang.

Rumusan masalah penelitian ini adalah "Bagaimana makna pada mural di jalan yang dihapus setelah viral?". Tujuan penelitian yang peneliti lakukan ialah untuk mengetahui makna pada mural di jalan yang dihapus setelah viral. 
Bernica Irnadianis Ifada, Suzy S. Azeharie: Studi Semiotika Pada Mural Di Jalan (Analisis Roland Barthes Pada Mural Yang Dihapus Setelah Viral)

\section{Metode Penelitian}

Pada penelitian ini peneliti menggunakan metode penelitian kualitatif secara deskriptif. Menurut Denzin dan Lincoln dalam Lexy J. Moleong penelitian kualitatif ini merupakan metode penelitian yang menafsirkan fenomena yang terjadi dengan melakukan serta melibatkan berbagai metode yang ada. Fokusnya adalah latar belakang ilmiah agar hasilnya dapat digunakan untuk menafsirkan suatu fenomena (Moleong, 2018). Singarimbun dan Effendi dalam Atwar Bajari mengatakan metode deskriptif merupakan alat ukur terhadap fenomena sosial tertentu dengan bertujuan untuk mengembangkan konsep dan fakta-fakta. Penelitian ini bertujuan untuk menggambarkan secara tepat sifat masing-masing individu, keadaan, dan menentukan penyebaran gejala yang memiliki hubungan antara satu gejala dan lainnya (Bajari, 2015). Penelitian ini ingin mengkaji makna pada mural di jalan yang dihapus setelah viral. Pendekatan kualitatif ini dipilih penulis karena penulis ingin mengetahui makna yang terkandung pada lukisan mural di jalan yang di hapus setelah viral.

Menurut Yin dalam Fitrah, studi kasus ialah proses pencarian untuk meneliti dan menyelidiki berbagai fenomena yang terjadi dalam konteks kehidupan nyata (Fitrah, 2018). Tujuannya adalah untuk menghasilkan makna, menyelidiki proses, dan memperoleh pemahaman (Sugiarto, 2015). Penulis memilih menggunakan metode ini karena fokus penelitian adalah unit tertentu, yang dapat berupa individu, organisasi, kelompok, atau komunitas.

Peneliti menggunakan metode observasi, studi kepustakaan dan studi dokumentasi. Di dalam penelitian ini peneliti juga melakukan pengolahan dan analisis data dengan melakukan observasi lalu peneliti menganalisis data serta mengolah data untuk menarik kesimpulan dari penelitian. Samiaji Sarosa menyatakan bahwa pengelolaan data pada kualitatif dimaksudkan untuk mengubah data yang masih mentah agar menjadi data yang lebih mudah dicerna dan dianalisis oleh peneliti (Sarosa, 2019).

Peneliti juga melakukan teknik triangulasi data agar peneliti dapat mengetahui perbandingan data dan informasi agar bersifat valid. Teknik triangulasi menurut Lexy J. Moleong merupakan teknik keabsahan suatu data yang memanfaatkan suatu yang lain. Maka dari itu dengan melakukan teknik triangulasi peneliti dapat melakukan pengecekan dan perbandingan terhadap berbagai sumber, metode ataupun teori temuan penelitian (Moleong, 2012).

\section{Hasil Temuan dan Diskusi}

Dalam melakukan analisis pada ketiga mural yang viral setelah dihapus, penulis menggunakan analisis semiotika Roland Barthes terhadap makna mural yang dihapus setelah viral. Metode denotasi, konotasi dan mitos semiotika Roland Barthes dipakai untuk mengetahui makna-makna mengenai mural yang dihapus setelah viral. 


\section{Mural 'TUHAN, AKU LAPAR!!'}

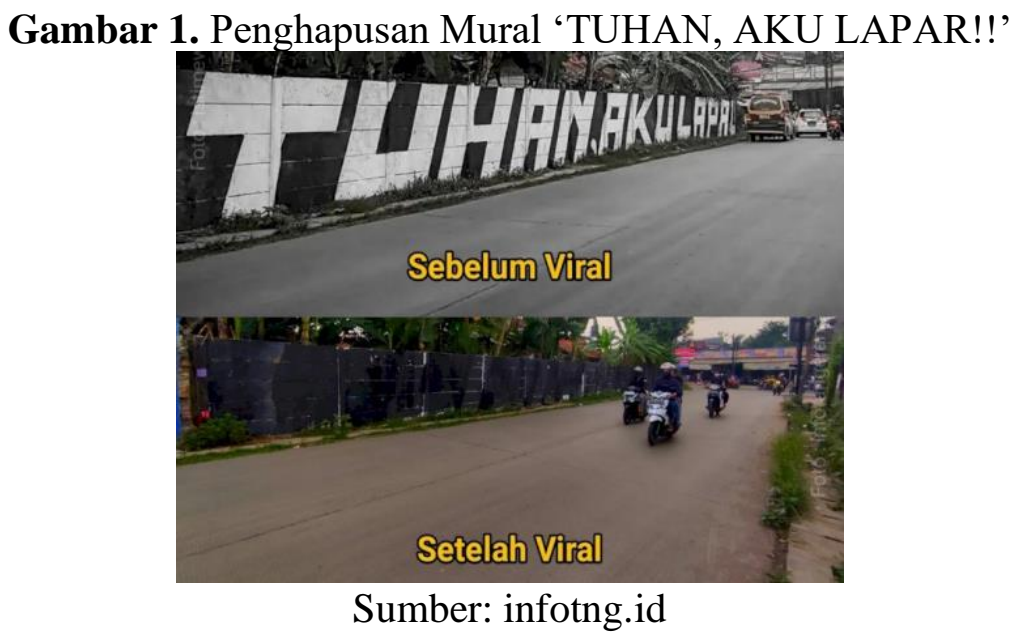

Mural 'Tuhan, Aku Lapar!!' yang belakangan ini viral di sosial media pada akhir Juli 2021 ini menjadi awal peristiwa penghapusan mural di beberapa kota besar di Indonesia. Mural ini berada di tembok pertigaan arah pasar Tigaraksa, Kabupaten Tangerang. Mural ini dibuat oleh Halfway Street Connection (HSC Forum). Mereka adalah komunitas yang menjadi wadah seniman yang menggeluti dunia seni untuk saling bertukar ilmu, belajar ilmu dan berpendapat (Agnes, 2021).

Denotasi dari lukisan mural tersebut menunjukkan tulisan TUHAN, AKU LAPAR!! dengan tulisan menggunakan huruf kapital dan ada dua tanda seru di akhir kalimat, tulisan tersebut berwarna putih pada latar dinding berwarna hitam.

Konotasi dari lukisan mural tersebut menunjukkan sosok muralis merasa putus asa karena disaat pandemi diterapkan kebijakan pemerintah seperti Pembatasan Sosial Berskala Besar(PSBB) dan lalu diganti dengan Pemberlakuan Pembatasan Kegiatan Masyarakat(PPKM) seperti ini membuat banyak industri kolaps. Perusahaan banyak yang menghentikan kegiatannya karena tidak ada permintaan dari pasar. Akibatnya Pemutusan Hubungan Kerja banyak terjadi. Untuk mencari pekerjaan baru sungguh bukan merupakan hal yang mudah karena kegiatan usaha dikurangi atau bahkan ditutup.

Mural di atas dibuat muralis dengan membuat mural seperti seakan-akan membuat pesan atau mengeluhkesahkan perasaannya kepada Tuhan melalui dinding dengan latar hitam dan tulisan TUHAN, AKU LAPAR!! dalam coretan bewarna putih. Warna hitam putih dalam kehidupan melambangkan kebaikan/keburukan, perbedaan, dan saling menghargai. Tanda seru yang digunakan muralis ini diperjelas sebagai tanda dari ungkapan pernyataan berupa kesungguhan atau adanya emosi yang kuat.

Mitos yang bekerja dalam mural ini adalah kesulitan yang dihadapi manusia bermuara kembali pada Tuhan. Kata Tuhan pada mural yang viral itu melambangkan bahwa agama bagi orang di Indonesia merupakan peranan yang sangat penting dalam kehidupan sehari hari. Terdapat enam agama di Indonesia antara lain 87,2\% sekitar 207 juta masyarakat Indonesia beragama Islam, 6,9\% beragama Kristen Protestan, 2,9\% beragama Katolik, 1,7\% beragama Hindu, 0,7\% beragama Buddha, dan 0,05\% lainnya beragama Khonghucu (Indonesia.go.id, 2021). 
Bernica Irnadianis Ifada, Suzy S. Azeharie: Studi Semiotika Pada Mural Di Jalan (Analisis Roland Barthes Pada Mural Yang Dihapus Setelah Viral)

\section{Mural 'Dipaksa Sehat di Negara yang Sakit'}

Gambar 2. Penghapusan Mural berjudul 'Dipaksa Sehat di Negara yang Sakit'

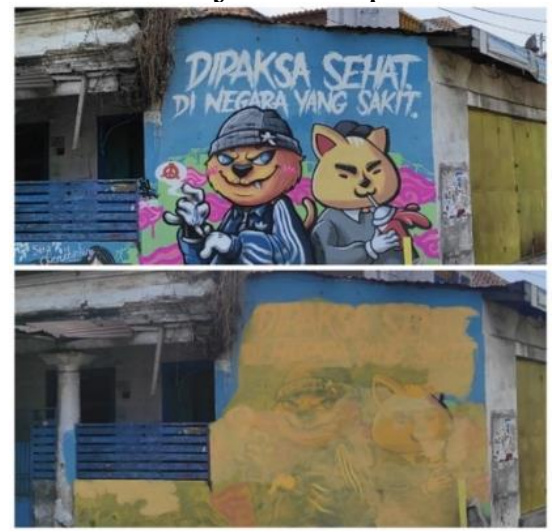

Sumber: Instagram @nganjukmelawan_

Mural berjudul 'Dipaksa Sehat di Negara yang Sakit' berada di sebuah dinding rumah kosong di ujung Jalan Diponegoro, Bangil, Pasuruan. Mural ini sudah ada sejak 2 Agustus 2021 namun pada tanggal 10 Agustus 2021 dihapus oleh aparat Satuan Polisi Pamong Praja Kabupaten Pasuruan.

Denotasi dari lukisan mural tersebut menggambarkan terdapat dua karakter kucing dengan latar belakang berwarna biru. Kucing yang pertama terlihat menggunakan jaket biru dan menggunakan topi abu-abu dan terlihat tersenyum menyeringai. Sementara kucing kedua terlihat menggunakan sweater abu-abu sambil minum. Di atas kedua karakter kucing tersebut terdapat tulisan 'DIPAKSA SEHAT DI NEGARA YANG SAKIT'. Huruf pada kalimat itu ditulis dengan menggunakan huruf kapital dan berwarna putih.

Konotasi dari lukisan mural tersebut menggambarkan sosok muralis yang mewakili perasaan kekecewaan rakyat terhadap pemerintah. Karena dalam mural tersebut diperjelas dengan tulisan 'dipaksa sehat' yang berarti masyarakat 'dipaksa sehat' pada masa pandemi Covid-19, 'di negara yang sakit'. Maksud dari negara yang sakit ini adalah muralis merasa ada yang salah dalam penanganan Covid di negeri ini. Karena pada tanggal 2 Maret 2020 pemerintah Indonesia pertama kali mengumumkan terdapat dua kasus pasien dinyatakan positif Covid-19 yang terjadi di Indonesia (Pranita, 2020) jumlah orang yang terinfeksi semakin banyak dan sebarannya semakin meluas. Seluruh wilayah kepulauan Indonesia tidak ada yang tidak terindeksi Covid. Kasus Covid-19 per 30 November 2021 di Indonesia yang positif 4.256 .409 orang, sembuh mencapai 4.104.657 orang, meninggal mencapai 143.830 orang (Covid19.go.id, 2021). Lalu, terhitung periode 17 Agustus 2021, tercatat terdapat 1.891 tenaga kesehatan Indonesia yang meninggal saat pandemi ini, diantara lain yaitu sebanyak 640 dokter, 98 dokter gigi, 637 perawat, 377 bidan, 33 ahli teknologi laboratorium, 34 ahli gizi dan 13 ahli kesehatan masyarakat Indonesia (BBC, 2021).

Mitos yang bekerja dalam mural ini adalah terdapat kucing yang menjadi simbol utama pada mural tersebut. Di masyarakat terdapat peribahasa "membeli kucing dalam karung" yang berarti ketika seseorang akan membeli sesuatu maka ia harus betul betul menimbang dengan seksama barang yang akan dibelinya itu, apakah memenuhi harapan, apakah baik, apakah dibutuhkan dan seterusnya. 
Lalu terdapat gambar dua kucing, kucing pertama terlihat menyeringai dan menggunakan pakaian training suit, kucing kedua terlihat menggunakan pakaian sweater berkerah dan sambil minum sebuah minuman. Kucing merupakan salah satu hewan peliharaan dan hewan kesayangan orang Indonesia. Menurut survei yang dilakukan Rakuten Insight (sebuah lembaga yang dibentuk oleh usaha eceran Rakuten yang berpusar di Tokyo, Jepang) menunjukkan hampir separuh atau $47 \%$ orang Indonesia memelihara kucing (Lokadata.id, 2021). Di Indonesia 87,2\% yaitu sekitar 207 juta masyarakat Indonesia beragama Islam. Orang Islam sangat sayang pada hewan kucing karena kucing dipercaya merupakan hewan kesayangan Nabi Muhammad SAW.

\section{Mural 404: Not Found}

Gambar 3. Penghapusan Mural '404: Not Found'

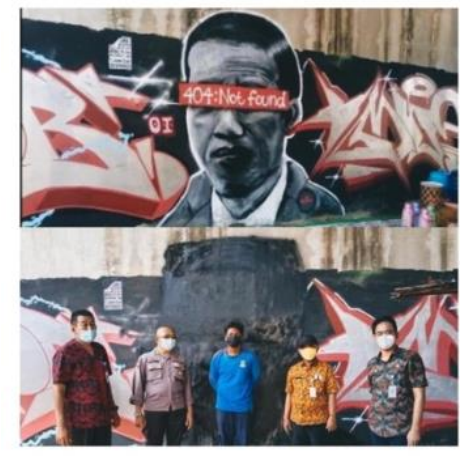

Sumber: fotokita.grid.id

Mural 404: Nout Found ini berada di Jalan Pembangunan I, Batujaya, Kec. Batuceper, Kota Tangerang, Banten. Mural ini diketahui ada sejak Agustus 2021 namun secara cepat langsung dihapus oleh aparat.

Denotasi dari lukisan mural tersebut sebuah wajah yang matanya ditutup dan yang diduga mirip wajah Presiden Joko Widodo berwarna hitam dan putih disertai teks 404 Not Found yang menutupi bagian matanya berwarna merah dan putih.

Konotasi dalam mural ini memiliki pesan yang digambar muralis dengan cara yang ekspresif dan memiliki banyak tafsir. Arti dari 404: Not Found menunjukkan bahwa sesuatu yang ingin diakses atau dicari dalam browser tidak dapat ditemukan atau dijangkau. Not Found atau "tidak ditemukan" merujuk pada keadaan bahwa pemimpin bangsa ini pada saat negara sedang dilanda pandemik tidak ada, tidak nampak bahwa ia mengatur, mengarahkan, mengendalikan negeri ini. Bisa juga merujuk pada keadaan bahwa negeri ini tidak ada yang memimpin atau "auto pilot", sebuah negeri yang berjalan sendiri tanpa ada pemimpin.

Mitos yang muncul dalam mural ini adalah jika suatu file yang dicari tidak ditemukan, maka akan ditulis '404: Not Found'. Selanjutnya adalah terdapat gambar pada mural yang mirip dengan Presiden Joko Widodo. Presiden Joko Widodo merupakan kepala negara Indonesia. Muralis menggambar sosok yang mirip dengan Presiden untuk memperjelas bahwa Presiden merupakan Kepala Negara Indonesia dan kepala Pemerintahan tidak ada di Indonesia. 
Mungkin muralis sengaja tidak menuliskan dengan jelas nama sosok gambar ini. Sebab ia tahu bahwa di Indonesia terdapat lima pasal penghinaan terhadap Presiden dan Wakil Presiden, yaitu: Pasal 134, Pasal 136 bis, Pasal 137 ayat (1), Pasal 137 ayat (2), Pasal 154, Pasal 155 ayat (1), dan Pasal 155 ayat (2).

\section{Mural sebagai Media Komunikasi}

Mural merupakan salah satu seni di jalanan yang digunakan sebagai media komunikasi yang cukup sering digunakan oleh masyarakat untuk menyampaikan pesan, harapan dan kritik kepada pihak yang mempunyai kekuasaan tertentu (Zulfikar, 2021).

Berdasarkan hasil wawancara dengan Sumbo Tinarbuko, mural adalah pola proses komunikasi yang dari zaman ke zaman memiliki tujuan yang hampir sama. Ketika seseorang mengalami hambatan dalam mengekspresikan pendapat atau pemikirannya maka ia akan mengungkapkannya melalui media lain. Media yang dipilih biasanya bersifat gratis dan aman untuk dikerjakan yaitu seperti mural.

\section{Ruang Publik}

Ruang publik menurut Habermas dalam Simarmata merupakan ruang yang dengan mudah dan dapat diakses tidak mengenal batas, bebas dari tekanan kekuasaan suatu negara dan ekonomi. Warga negara melakukan pembicaraan topik politik untuk mewujudkan suatu bentuk kesepahaman bersama terkait dengan kepentingan umum yang lebih luas (Simarmata, 2014).

Berdasarkan hasil wawancara dengan Sumbo Tinarbuko, ruang publik dijadikan sebagai media untuk menuangkan ekspresi agar pesan itu tersampaikan kepada orang banyak agar aspirasinya didengar, pandangan mereka direspon baik positif atau negatif.

\section{Kelompok Bungkam}

Menurut Edwin dan Shirley Ardener dalam Richard West dan Lynn H. Turner menyatakan bahwa teori Kelompok Bungkam merupakan kelompok yang menyusun bagian teratas dari hierarki sosial untuk menentukan sistem komunikasi pada budaya tersebut. Kelompok dengan kekuasaan yang lebih rendah harus belajar bekerja pada sistem komunikasi yang telah dikembangkan oleh kelompok dominan (West dan Turner, 2010).

Menurut Edwin dan Shirley Ardener dalam Sebayang, Rakyat marjinal sering diartikan sebagai kaum yang berada pada posisi sebagai kelompok bungkam. Maka dari itu ide atau konsep mengenai rakyat yang berkaitan dengan kedudukannya dibandingkan pemimpin menjadi jelas. Hal itu merupakan kelompok marjinal yang terpinggirkan dan mengikuti bagaimana sebuah sistem hierarki dan struktur sosial yang dibangun oleh kelompok dominan (Sebayang, 2016).

Berdasarkan hasil wawancara dengan Sumbo Tinarbuko, muralis adalah rakyat. Rakyat juga berhak bersuara, namun banyak cara yang dilakukan rakyat. Muralis menyuarakan pendapat atau ekspresi yang dirasakan rakyat dengan cara menggambar mural atau membuat komunikasi visual. Namun mural ini kerap menimbulkan banyak kegaduhan lalu petugas atau aparat secara reaktif menghapus pesan-pesan itu sebagai bentuk ketidaksepahaman atau pembungkaman. 


\section{Simpulan}

Dari hasil penelitian dan pembahasan mengenai makna pada mural di jalan yang di hapus setelah viral, maka penulis mengambil beberapa kesimpulan sebagai berikut:

Pertama, Mural tidak ada bedanya dengan sebuah pesan yang dikirimkan seseorang melalui pesan layanan singkat. Pesan itu akan dengan mudah dihapus oleh penerimanya atau bahkan pengirim pesan akan di blokir karena pesan yang diterima dianggap menggangu atau tidak sesuai dengan harapan penerimanya. Mural-mural yang viral dan membuat heboh belakangan ini adalah bentuk komunikasi antara masyarakat dan pemerintah dengan cara yang lebih ekspresif dan memiliki banyak tafsir. Mural sebenarnya adalah pola pola proses komunikasi yang dari zaman ke zaman memiliki tujuan yang hampir sama. Seseorang ketika mengalami hambatan dalam mengekspresikan pendapat atau pemikirannya maka ia akan mengungkapkannya melalui media lain. Media yang dipilih biasanya bersifat gratis dan aman untuk dikerjakan.

Kedua, pada ketiga mural yang dibahas, mural tersebut dijadikan sebagai respon atas kinerja pemerintah atau kritik sosial bukanlah hal yang baru terjadi di Indonesia. Di ruang publik biasanya muralis ingin pesan yang disampaikan ini tersampaikan untuk orang banyak, agar aspirasinya didengar, pandangan mereka direspon baik positif atau negatif.

Ketiga, muralis adalah rakyat. Rakyat juga berhak bersuara, namun banyak cara yang dilakukan setiap rakyat. Muralis ini menyuarakan pendapat atau ekspresi yang dirasakan rakyat dengan cara menggambar mural. Namun mural ini kerap menimbulkan banyak kegaduhan lalu petugas atau aparat secara reaktif menghapus pesan-pesan itu sebagai bentuk pembungkaman.

\section{Ucapan Terima Kasih}

Rasa syukur peneliti panjatkan kepada Allah SWT karena atas rahmat-Nya, peneliti dapat menyelesaikan laporan penelitian ini dengan tepat waktu. Oleh sebab itu, peneliti ingin mengucapkan banyak terima kasih kepada Ibu Suzy S Azeharie selaku dosen pembimbing peneliti dan juga kepada orang yang telah membantu dan memberi dukungan yang luar biasa selama pengerjaan penelitian ini, yaitu keluarga, narasumber dan teman-teman yang peneliti sayang dan yang tidak hentinya memberi doa dan dukungan.

\section{Daftar Pustaka}

Bajari, Atwar. (2015). Metode Penelitian Komunikasi Prosedur, Tren, dan Etika. Bandung: Simbiosa Rekatama Media.

BBC. (2021). Diakses dari https://www.bbc.com/indonesia/indonesia-58345226.

Covid19.go.id. (2021). Diakses dari https://covid19.go.id/.

Fitrah, M. (2018). Metodologi penelitian: penelitian kualitatif, tindakan kelas \& studi kasus. CV Jejak (Jejak Publisher).

Indonesia.go.id. (2021). Diakses dari https://indonesia.go.id/profil/agama.

Kompas. (2020). Diakses dari https://nasional.kompas.com/read/2020/07/13/09361841/survei-litbangkompas-878-responden-tak-puas-pada-kinerja-menteri-tangani?page=all. 
Bernica Irnadianis Ifada, Suzy S. Azeharie: Studi Semiotika Pada Mural Di Jalan (Analisis Roland Barthes Pada Mural Yang Dihapus Setelah Viral)

Lokadata. (2021). Diakses dari https://lokadata.id/artikel/hampir-separuh-orangindonesia-piara-kucing-asia-pilih-anjing.

Moleong, Lexy J. (2012). Metodologi Penelitian Kualitatif. Bandung: PT Remaja Rosdakarya.

Nasruddin, R., \& Haq, I. (2020). Pembatasan sosial berskala besar (PSBB) dan masyarakat berpenghasilan rendah. SALAM: Jurnal Sosial dan Budaya Syari, 7(7), 639-648.

Sarosa, Samiaji (2017). Penelitian Kualitatif : Dasar-Dasar. Jakarta : Indeks Jakarta.

Simarmata, S. (2014). Media baru, ruang publik baru, dan transformasi komunikasi politik di Indonesia. Jurnal Interact, 3(2), 18-36.

Sugiarto, E. (2015). Menyusun Proposal Penelitian Kualitatif: Skripsi dan Tesis. (Penerbit Suaka Media (Ed.)).

West, Richard \& Lynn H. Turner.. (2010). Pengantar Teori Komunikasi. Jakarta: Salemba Empat. 